WW W. TER A PE V TY K A. C O M.U A

\title{
ОСНОВНІ ПРИНЦИПИ ПРОФІЛАКТИКИ СТОМАТОЛОГІЧНИХ ЗАХВОРЮВАНЬ
}

\author{
3.Б. Попович, М.М. Рожко
}

Івано-Франківський національний медичний університет, м. Івано-Франківськ

Резюме. Проблема стоматологічної захворюваності має велике медичне та соціальне значення. Спостерігається збільшення поширеності та інтенсивності патології твердих тканин зубів та пародонта в різних вікових груп населення, особливо серед дітей. Так, поширеність стоматологічних захворювань становить 83,6-95,3\%, а у деяких місцевостях — до 99,5\%.

Мета роботи - огляд і систематизація літературних даних, присвячених питанням профрілактики стоматологічних захворювань.

Висновок. Заходи, спрямовані на збереження стоматологічного здоров'я, мають бути тривалими, довгостроковими, і про це необхідно пам'ятати, плануючи програми гігієнічного навчання та виховання населення — складової частини системи комплексної профрілактики стоматологічних захворювань.

Ключові слова: профрілактика стоматологічних захворювань, патогенна мікрофрлора, мікроелементи.

\section{Main principles of dentist diseases prevention}

\section{Z.B. Popovych, M.M. Rozhko \\ Ivano-Frankivsk National Medical University, Ivano-Frankivsk}

Abstract. The problem of dental morbidity is of great medical and social importance. There is an increase in the prevalence and intensity of pathology of the hard tissues of the teeth and periodontium in different age groups, especially among children. Thus, the prevalence of dental diseases is $83.6-95.3 \%$, and in some areas up to $99.5 \%$.

The aim of the work is to review and systematize literature data, devoted to the prevention of dental diseases.

Conclusion. Measures aimed at maintaining dental health should be long-term, long-term, and this should be borne in mind when planning programs of hygienic education and upbringing of the population - part of a system of comprehensive prevention of dental diseases.

Keywords: prevention of dental diseases, pathogenic microflora, microelements.

УДК: 616.314-084+616.314-002 DOI: $10.31793 / 2709-7404.2021 .2-2.35$

() 3.Б. Попович, М.М. Рожко

Надійшла до редакції 03.06.2021

Адреса для листування (Correspondence): Івано-Франківський національний медичний університет, вул. Галицька, 2, м. Івано-Франківськ, 76018, Україна. E-mail: zdovado@ukr.net 
У цілях сталого розвитку ООН до 2030 року здоров'я населення посідає центральне місце та представлено під номером 3 - «Забезпечення здорового способу життя та сприяння благополуччю для всіх». Відповідно до декларації В003, створення середовища, яке сприяє збереженню та зміцненню здоров'я, $є$ одним із головних завдань у галузі охорони здоров'я, у тому числі в стоматології.

В Україні проблема стоматологічних захворювань має вагоме медичне та соціальне значення. Спостерігається збільшення поширеності та інтенсивності патології твердих тканин зубів і пародонта в різних вікових груп населення, особливо серед дітей. Так, поширеність стоматологічних захворювань становить 83,6-95,3\%, а в деяких місцевостях сягає до 99,5\% [2, 6-8]. Незважаючи на те, що вивченню етіології карієсу та захворювань пародонта присвячено багато наукових праць дослідників усього світу, це питання продовжує вивчатися. У розумінні комплексного піклування про здоров'я дітей та підлітків на перший план виступає профілактичний аспект. Незважаючи на вже давно відоме твердження, що «запобігти легше, ніж потім лікувати», просрілактика стоматологічних захворювань тривалий час була на низькому рівні та повністю відірвана від практичних заходів [5]. У стоматології протягом багатьох років прийнято було вважати головною метою запобігання хворобам ротової порожнини, але це було лише декларацією на папері, a, по суті, основним був напрямок відновлювального лікування [5]. Можливо, це є однією із багатьох причин високого рівня стоматологічної захворюваності в Україні.

Мета цієї роботи - огляд і систематизація літературних даних, присвячених питанням профрілактики стоматологічних захворювань. Наявні в розпорядженні В003 епідеміологічні дані [6-8] свідчать про велику різницю в поширеності карієсу зубів у різних регіонах світу. Загалом визначаються дві тенденції в зміні стоматологічного статусу: погіршення в більшості країн, що розвиваються, та покращення в більшості високорозвинутих країн.

Останніми роками спостерігається активний розвиток профілактичного напрямку стоматології, і цьому передує низка умов. Незвичним $€$ значна поширеність та інтенсивність раннього карієсу (early childhood caries - ECC) серед дітей від народження до 71 місяця, що спостерігається навіть у високорозвинутих країнах [1]. У США за останні десять років поширеність карієсу тимчасових зубів серед дітей віком від 2 до 5 років зросла на 15,2\%, причому 8,4\% дворічних дітей мають один каріозний або запломбований зуб [1]. В Україні цей показник серед дітей такого віку іноді сягає $60 \%[1,2]$, що зумовлює актуальність цього питання для системи охорони здоров'я нашої держави. Значна увага до множинних (важких) форм карієсу в дітей (severe early childhood caries - SECC) стає зрозумілою з огляду на вагомість його впливу на загальний стан здоров'я маленької дитини [1, 2]. Оптимально, щоб акцент на профрілактику був зроблений ще в антенатальний період, у вагітних жінок, за допомогою інтегрованих зусиль стоматологів, акушерів-гінекологів, педіатрів, батьків. Вагітність матері є важливим періодом у формуванні стоматологічного здоров'я дитини. Необхідним методом організації стоматологічної допомоги, актуальним у сучасних умовах, є проведення стоматологічної диспансеризації вагітних жінок.

Вважається, що для виникнення карієсу необхідно три основні умови: сприйнятливі тверді тканини зуба, наявність патогенної мікросрлори та високий рівень вуглеводів. Але, крім цього, велике значення має загальний стан здоров'я дитини, екологічні умови проживання, якість харчування тощо [2].

Сприйнятливість твердих тканин зубів зумовлюється їх структурою та хімічним складом. Найвразливішими $є$ тканини в період завершальної мінералізації. При цьому важливу роль відіграють характер харчування, гормональні та метаболічні порушення, системні захворювання. На виникнення та розвиток каріозного процесу впливають і місцеві чинники: наявність ортодонтичної патології, висока в'язкість слини, недостатні буферні властивості слини тощо.

Основним етіологічним фактором більшості стоматологічних захворювань $є$ бактеріальний біофрільм (біоплівка). Сучасні дані свідчать, що в нормі в порожнині рота наявні близько 7 тис. мікроорганізмів [9]. Однак за відсутності гігієни їх кількість значно зростає та досягає 2-3 млн, що призводить до реакції з боку імунної системи. Відповідно, якщо пацієнт не дотримується правил індивідуальної гігієни, біофрільм збільшується, ущільнюється і в подальшому призводить до демінералізації твердих тканин зубів.

У результаті досліджень мікрофрлори різних біотопів порожнини рота з використанням сучасних методів та підходів із точки зору доказової медицини визначено склад мікрофлори порожнини рота в нормі і при патологічних станах [3, 4] (табл.). 


\section{Таблиця}

Склад мікрофлори порожнини рота в нормі і при патологічних станах за Савичук Н.О. (адаптовано за Р.ДЖ. Ламонт і співавт., 2010)

\begin{tabular}{|c|c|}
\hline Зуби & Streptococcus (Str.) mitis біовар 1, Str. gordonii, Str. sanguis, Str. oralis, вейлонели, актиноміцети \\
\hline Язик & Str. mitis, Str. salivarius \\
\hline \multicolumn{2}{|l|}{ При патологічних станах } \\
\hline Kapi€c & Str. mitis біовар 1, Str. gordonii, Str. sanguis, Str. oralis, Str. mutans, актиноміцети, лактобактерії \\
\hline Ускладнений карієс & $\begin{array}{l}\text { Bacteroides, Prevotella, Lactobacillus, Streptococcus spp., Clostridium, Fusobacterium, Peptostreptococcus, } \\
\text { Corynebacterium, Bifidobacterium, Capnocytophaga, Actinomyces, Leuconostoc, Porphiromonas, Candida, } \\
\text { Veillonella, Gemella, Staphylococcus, Aerococcus, Saccharomyces, Enterococcus, Eubacteria }\end{array}$ \\
\hline Гінгівіт & $\begin{array}{l}\text { Actinomyces: naeslundii, viscosus, israelii; Str. sanguis, Str. mitis; Fusobacterium nucleatum, Selenomonas } \\
\text { sputigena, Haemophilus parainfluenzae, пептострептококи, Prevotella intermedia, Campylobacter sputorum, } \\
\text { вейлонели }\end{array}$ \\
\hline Пародонтит & $\begin{array}{l}\text { Клон } 1025 \text { TM7, Fusobacterium nucleatum animalis, Atopobium parvulum, } \\
\text { Eubacterium spp. штам PUS9.170, Abiotrophia adiacens, Dialister pneumonitis, Filifactor alocis, Selemonas } \\
\text { spp. штам GAA14, Str. constellatus, Campylobacter rectus, Tannerella forsythia, porphyromonas } \\
\text { endodontalis, Wolinella recta, Treponema spp. штам I: G: T21, Fusobacterium nucleatum, Atopobium } \\
\text { rimae, Megasphaera spp. клон BB166, Catonella morbi, Eubacterium saphenum, Gemella haemolysans, } \\
\text { Str. anginosus, Campylobacter gracilis, Haemophilus parainfluenzae, Prevotella tannerae, Porphyromonas } \\
\text { gingivalis, Peptostreptococcus micros }\end{array}$ \\
\hline Локалізований пародонтит & $\begin{array}{l}\text { Eikenella corrodens, Capnocytophaga sputigena, Actinobacillus actinomycetemcomitans, Prevotella } \\
\text { intermedia }\end{array}$ \\
\hline Стоматит & 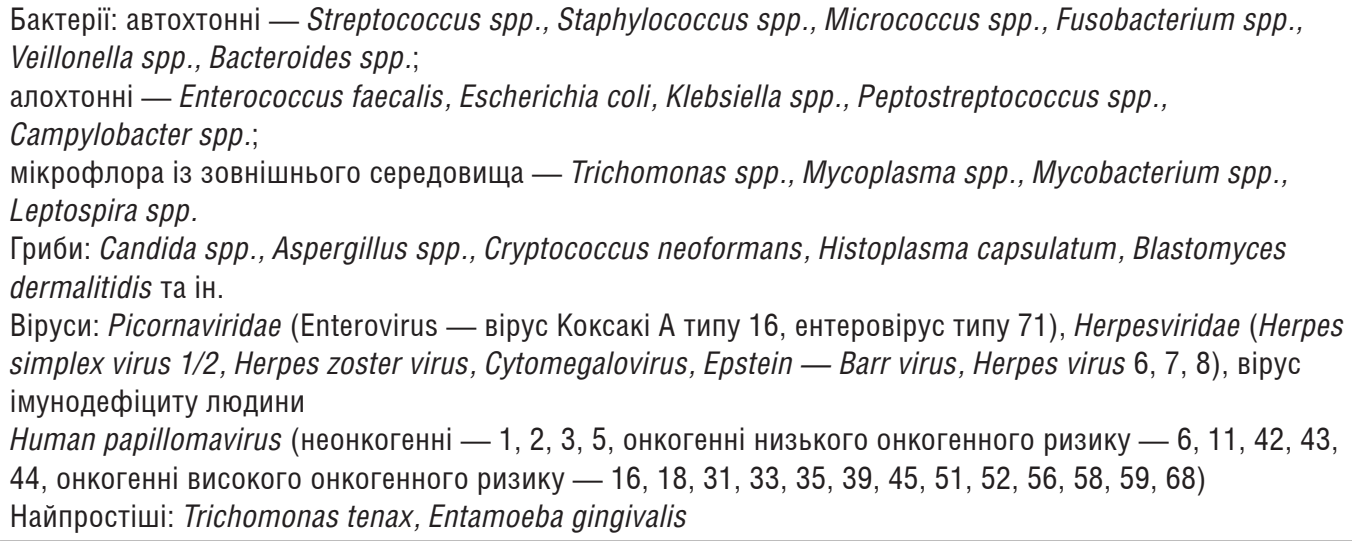 \\
\hline
\end{tabular}

Таким чином, наявність домінуючої більшості патогенних мікроорганізмів у порожнині рота $€$ передумовою формування та прогресування стоматологічних захворювань — карієсу (у тому числі ускладненого), гінгівіту, пародонтиту, захворювань СОПР, періімплантиту, абсцесів, флегмон та ін. [3, 4].

Іноді може виникати транзиторна бактеріємія — це ризик гематогенного шляху поширення патологічної мікрофлори порожнини рота, що характеризується наявністю життєздатних бактерій у системному кровотоці. Бактеріємія $€$ поширеним явищем, яке виникає внаслідок травмування слизової оболонки, що в нормі містить ендогенну флору. Відповідно до сучасних даних, за наявності гінгівіту до системного кровотоку під час стоматологічних маніпуляцій потрапляє близько 20\% бактерій, при пародонтиті цей відсоток є ще вищим та становить $75 \%$ - при стоматологічних процедурах та $15-20 \%$ - при звичайному жуванні [9].

Натомість нормальна мікроекологія порожнини рота необхідна для підтримання фізіологічного стану та функціонування слизової оболонки, пародонтального комплексу, твердих тканин зубів, слинних залоз та сумісних слизових оболонок (травного каналу, ЛОР-органів та органів дихання). Стан колонізаційної резистентності порожнини рота пов'язаний із функціонуванням єдиної лімфоїдної системи слизових оболонок [3, 4]. Сучасні дані свідчать, що з метою профілактики утворення патологічного біофільму в порожнині рота необхідно кожні 8-12 год його усувати, тобто 
дотримуватися правил особистої гігієни ротової порожнини. У разі якщо цей біосрільм протягом 8-12 год не було усунуто, він починає рости та розмножуватися - життєвий цикл біоплівки, який призводить до формування зрілої структури, що має здатність формувати матрикс та колонії, які в подальшому поширюються на оточуючі тканини [9]. Як наслідок, ці стійкі зрілі біоплівки вже неможливо усунути звичайними засобами гігієни, що потребує застосування професійної гігієни ротової порожнини.

Велике значення для розвитку стоматологічних захворювань має вміст мікроелементів у твердих тканинах зубів. Протягом життя людини емаль бере участь в обміні іонів, зазнаючи процесів демінералізації і ремінералізації, які у фізіологічних умовах збалансовані. Кількісний вміст хімічних елементів в емалі не є сталою величиною, а динамічно змінюється під впливом різних чинників [2].

Стійкість зубів до карієсу значною мірою визначається складом і властивостями емалі. Усього в емалі нараховується близько 40 різних мікроелементів. У поверхневих шарах емалі в найбільшій концентрації знаходяться такі мікроелементи: $\mathrm{F}, \mathrm{Ca}, \mathrm{Zn}, \mathrm{Pb}, \mathrm{Fe}$. У глибоких шарах сконцентровані $\mathrm{Na}$ і $\mathrm{Mg}$, більш-менш рівномірно розподілені по всій товщині емалі $\mathrm{Sr}, \mathrm{Cu}, \mathrm{Al}$ i K.

J. Navia [11] ще декілька десятиліть тому розподілив мікроелементи по групах залежно від їх відношення до карієсу зубів. Це підтверджують і інші вчені [12, 18-20]. Перша група елементи, які сприяють виникненню карієсу (Mg, Pb, Se, Cd, Si). Друга група - елементи з вираженою ( $\mathrm{i} \mathrm{P,} \mathrm{Ca)} \mathrm{та} \mathrm{маловираженою} \mathrm{(Mo,}$ $\mathrm{V}, \mathrm{Cu}, \mathrm{Sr}, \mathrm{B}, \mathrm{Li}, \mathrm{Au}$ ) протикаріозною дією. Також у літературі є дані, що Mg знижує абсорбцію $\mathrm{Ca}$ в кишечнику, а недостатність Mn може зумовити затримку росту та розвитку зубів. Знижує карієсрезистентність емалі підвищений вміст у ній свинцю, магнію, марганцю $[12-15,18,19]$.
На карієсрезистентність твердих тканин можуть впливати порушення функції слинних залоз, зміни біохімічного складу рідин організму при загальних захворюваннях, реакція центральної нервової системи.

Крім перерахованих чинників, на стан резистентності емалі впливають перенесені та супутні захворювання, гіпо- та авітамінози, характер харчування, вміст фтору в питній воді, екологічні умови проживання. Важливе значення має стан органів та систем у період фрормування тканин зубів. Багатьма вченими доведено, що при патології шлунково-кишкового тракту, опорно-рухового апарату, ендокринних порушеннях, порушенні обміну речовин кількість стоматологічних захворювань значно зростає.

\section{Висновок}

Профрілактичний напрямок останніми роками відіграє все важливішу роль у системі сучасної медицини, це стосується і стоматології. Протягом багатьох років профрілактика часто була на рівні декларування, без належного матеріального забезпечення та фінансування. Для покращення стоматологічного здоров'я на рівні популяції необхідно об'єднати зусилля профрільних спеціалістів (стоматологів, педіатрів, гінекологів, сімейних лікарів) та суспільства загалом. Має сформуватися громадська думка, що турбуватися про стоматологічне здоров'я необхідно так, як і про свою зовнішність, матеріальне благополуччя. Усі зусилля, які необхідно докласти, щоб мотивувати людей на збереження стоматологічного здоров'я, мають бути тривалими, довгостроковими, і про це необхідно пам'ятати, плануючи програми гігієнічного навчання та виховання населення - складової частини системи комплексної профрілактики стоматологічних хвороб.

\section{Список використаної літератури}

1. Якубова II. Впровадження схеми диспансеризації вагітних жінок у стоматолога - перший крок до збереження стоматологічного здоров'я матері і формування його у дитини. Новини стоматології. 2012;2:56-59.

2. Попович ЗБ, Рожко ММ, Безвушко ЕВ. Карієс та його ускладнення у дітей. Навч. посібн. $2020: 236$.

3. Савичук НО. Колонізаційна резистентність слизової оболонки порожнини рота (4. 1). Совр. стоматол. 2011;2:66-72.

4. Савичук НО. Колонізаційна резистентність слизової оболонки порожнини рота - учасні підходи до корекції (4. 2). Совр. стоматол. 2011:3:87-91.

5. Каськова ЛФ (ред.). Профрілактика стоматологічних захворювань: підруч. для студ. вищих мед. навч. закл. Х.: Факт, 2011:392.

6. Терапевтична стоматологія дитячого віку. Том 1: підруч. За ред. профр. ЛО Хоменко. К.: Книга плюс, 2014:432. 
7. Терапевтична стоматологія дитячого віку. Том 2: підруч. За ред. профр. ЛО Хоменко. К.: Книга плюс, 2016:328.

8. Х Хоменко ЛО, Шматко ВІ, Остапок ОІ, Біденко НВ та співавт. Стоматологічна профрілактика у дітей. Навч. посібн. 1993:190.

9. Слободяник М. Протимікробна резистентність: механізми формування, клініка та діагностика. Український медичний часопис. 2021. Доступно: https://www.umj.com.ua/article/204645/mikrobnij-biofilm-u-formuvanni-protimikrobnoyi-rezistentnosti

10. Левицкий АП, Волянский ЮЛ, Скидан КВ. Пробиотики и проблема дисбактериоза. Харків: ЄДЄНА, $2008: 100$.

11. Navia JM. Prevention of dental caries: Agents which increase tooth resistance to dental caries. Int. Dent. J. 1972;22:27-40.

12. Pathak MU, Shetty V, Kalra D. Trace Elements and Oral Health: A Systematic Review. Journal of Advanced Oral Research. 2015;7(2):12-20

13. Bartols A, Walther W, Dörfer CE. First Evidence for Regeneration of the Periodontium to Mineral Trioxide Aggregate in Human Teeth. Journal of Endodontics. 2017;43(5):715-722.

14. Al-Jorrani MS, El-Sammarai SK. Concentrations of selected elements in permanent teeth and enamel among a group of adolescent girls in relation to severity of caries. J. Bagh Coll Dent. 2013;25:176-80.

15. Benghsheer HF, Hussein AS, Abu-Hassan MI. Salivary sodium and potassium in relation to dental caries in a Group of Multiracial School Children. J. Dent. 2013;3:307-13.

16. Plum LM, Rink L, Haase H. The essential toxin: Impact of zinc on human health. Int. J. Environ Res. Public Health. 2010;7:1342-65.

17. Rao KS, Anupama PM, Mahesh DG, Rao RV, Rautray TR, Venkateshwarulu P. Trace elemental analysis of dental caries in human teeth by external PIXE. Int. J. Appl. Biol. Pharm. Technol. 2010;1:68-78.

18. Hussein AS, Ghasheer HF, Ramli NM, Schroth RJ, Abu-Hassan MI. Salivary trace elements in relation to dental caries in a group of multi-ethnic schoolchildren in Shah Alam, Malaysia. Eur. J. Paediatr. Dent. 2013;14:113-8.

19. Rahmani M, Ghorchi V, Rezaei F, Vaisi-Raygani A. Evaluation of total antioxidant capacity of saliva in high school students. Glob. J. Health Sci. 2015; 8:89-94. https://doi.org/10.5539/gjhs.v8n4p89

20. Buczko P, Zalewska A, Szarmach I. Saliva and oxidative stress in oral cavity and in some systemic disorders. J. Physiol. Pharmacol. 2015;66:3-9. 